\title{
Tinjauan sistematis: Efektifitas Palliative Home Care untuk Pasien dengan HIV/AIDS
}

\author{
Linlin Lindayani', Nenden Nur Asriyani Maryam² \\ ${ }^{1}$ STIKEP PPNI Jawa Barat, ${ }^{2}$ Fakultas Keperawatan, Universitas Padjadjaran \\ Email: maryamnenden@yahoo.co.id
}

\begin{abstract}
Abstrak
Asuhan palitif untuk pasien dengan HIV/AIDS merupakan elemen inti dari asuhan pasien dengan HIV/ AIDS. Asuhan paliatif yang berbasis home care saat ini menjadi elemen penting yang digunakan di berbagai negara. Akan tetapi, tidak ada studi atau tinjauan sebelumnya yang menganalisis efektifitas dari asuhan paliatif yang berbasis home care pada pasien dengan HIV/AIDS. Tujuan dari tinjauan sistematik ini adalah untuk mengevaluasi efektivitas Palliative Home Care untuk pasien dengan HIV/AIDS terhadap nyeri, pengendalian gejala, meningkatkan kualitas hidup, meningkatkan kepuasan asuhan, dan efektivitas biaya. Pencarian awal terbatas dilakukan di MEDLINE dan CINAHL. Kedua database tersebut dipilih dengan pertimbangan bahwa keduanya merupakan database terbesar di bidang kesehatan dan kedokteran. Kemudia strategi pencarian lainnya dilakukan pada database lain meliputi: Cochrane Library, UpToDate, Ovid, AIDS Care, Journal of Palliative Care, dan Journal of Palliative Medicine. Studi yang diterbitkan dalam Bahasa Inggris dan tahun 2000-2016 dipertimbangkan untuk dimasukkan dalam tinjauan ini. Data diekstrak oleh penulis dan diringkas menggunakan alat ekstraksi data dari JBI (Joanna Briggs Institute). Kami menemukan 4 studi yang masuk kedalam kriteria tinjauan kami, satu studi randomizes control trial dan tiga studi prospectively control. Hasil dari tinjauan ini menunjukkan bahwa Palliative Home Care terbukti efektif dalam mengontol nyeri dan gejala-gelaja lain, mempertahankan dan meningkatkan kualitas hidup pasien, tingginya kepuasan dari pasien dan kelurga terhadap asuhan Palliative Home Care berkisar 93\% - 96\% dan lebih cost-effectiveness dibandingkan dengan Hospital-Based Palliative Care. Dengan demikian, penting untuk mengembangkan Palliative Home Care untuk pasien dengan HIV/AIDS terutama untuk negara dengan sumber daya yang terbatas.
\end{abstract}

Kata kunci: Asuhan keperawatan paliatif, paliative home care, patients with HIV/AIDS.

\section{Effectiveness of Palliative Home Care for Patients with HIV/AIDS: A Systematic Review}

\begin{abstract}
Palliative care for patients with HIV/AIDS is a core element of HIV/AIDS care, Home-based palliative care is increasingly being used as a key management strategy in many countries. No systematic review has assessed the effectiveness of palliative home care for patients with HIV/AIDS. The objective of this review was to evaluate the effectiveness of home palliative care services for patients with HIV/AIDS on pain and symptoms control, improve quality of life, increase satisfaction of care, and cost effectiveness. Fist an initial limited search of MEDLINE and CINAHL was conducted to screen the exiting studies on palliative home care in patients with HIV/AIDS. These databased were chosen for initial search because that was considered as larger database for health and medical studies. Further searching strategy was conducted by utilizing another databases included: Cochrane Library, UpTodate, Ovid, AIDS care, Journal of palliative care, Journal of palliative medicine. Studies published in English and in years 2000-2016 were included in this review. Data extracted by the reviewers and summarized using the Joanna Briggs Institute (JBI) data extraction tool. We only included 4 studies that met ours inclusion criteria, one studies was randomize controlled trial and three studies were conducted using prospectively control study. The result of this review showed that palliative home care was effective to control pain and symptoms, maintains and improve quality of life, high patients and family satisfaction scores (ranged from $93 \%$ to $96 \%$ ), and more cost effectiveness rather that hospital-based palliative care. Thus, it's imperative to develop palliative home care for patients with HIV/AIDS especially those lived in limited resources country.
\end{abstract}

Keywords: Palliative home care, patients with HIV/AIDS. 
Linlin Lindayani: Tinjauan sistematis: Efektifitas Palliative Home Care untuk Pasien

\section{Introduction}

Palliative care for patients with HIV/AIDS is a core element of HIV/AIDS care, not as a substitute (Simms, Higginson, \& Harding, 2011; World Health Organization, 2005). The large evidence has been reported that palliative care is effective in pain and symptoms control, reducing anxiety, and improves patients' quality of life (Simms, Higginson, \& Harding, 2011; Goodwin, Higginson, Myers, Douglas, \& Normand, 2003; Harding et al., 2005; Selwyn et al., 2003). In addition, palliative care also has positive impact to the mortality rate. It unlikely the effect of antiretroviral therapy in reducing the mortality rate caused by AIDS (Jameson, 2007).

Palliative care services can be provided in the hospital, hospice, and ambulatory setting, or at home (WHO, 2005). The delivery of palliative care services for patients with AIDS will vary based on the specific circumstances in different countries and the level of resources available. The delivery of palliative care services for patients with AIDS will vary based on the specific circumstances in different countries and the level of resources available. For example, in sub-Sahara Africa, palliative care focused on pain control management for HIV/AIDS and cancer patients in home-based care and inpatients hospice care and provided successfully at community level with specialist support (Kikule, 2003). In Vietnam, integrated palliative care into routine HIV outpatient focused on pain and symptom control, depression and perceived social support (Krakauer, Ngoc, Green, Van Kham, $\&$ Khue, 2007). Home-based palliative care is increasingly being used as a key management strategy in many countries, especially in developing country where the public health services are already overburdened with limited human and financial resources (Young \& Busgeeth, 2010). Home-based palliative care is defined as any form of care given to ill people in their homes include physical, psychosocial, and spiritual activities with the goal to helps ill people and families to maintain their independence and achieve the best possible quality of life (WHO, 2002).

Indonesia is an archipelagic country of
17.508 (6.000 inhabited). The country's strategic sea-lane position fostered interisland. The archipelago's landform significantly influenced health care system in Indonesia (Indonesian Ministry of Health, 2013). As the developing country, the majority of the HIV cases arise and accessibility to public health services are remains limited and hospital admissions related to $\mathrm{HIV} /$ AIDS care still accounts for a big proportion of the expenditures for people with AIDS (Floyd, 2001). Access to get highly active antiretroviral therapy (HAART) is limited even though since 2004 HAART was free for all patients with HIV/AIDS. Around 65\% patients with HIV/AIDS get HAART from total patients that should get HAART. There are only 262 Hospital that provides HAART in level province and city, whereas Indonesia is huge country. Bed occupied at hospital for patients with HIV/AIDS is also limited (Indonesian Ministry of Health, 2013).

However, A few studies have compared outcomes with different palliative care models. Therefore, it is crucial to ascertain the effect of these services on outcomes of palliative care, such as symptom control, quality of life, and satisfaction with care, and the cost effective. No systematic review has assessed the impact of HIV/AIDS palliative home care. In considering this approach the evidence of its effectiveness needs to be evaluated as an essential first step. The purpose of this study is to evaluate the effectiveness of home palliative care services for patients with HIV/AIDS on pain and symptoms control, improve quality of life, increase satisfaction of care, and cost effectiveness through systematic review.

\section{Methods}

This study was conducted using a systematic review to evaluate effectiveness of palliative home care in people living with HIV/AIDS.

\section{Search strategy}

The search strategy aims was to find published studies. An initial limited search of MEDLINE, CINAHL, Cochrane Library, UpTodate, Ovid, AIDS care, Journal of 
Linlin Lindayani: Tinjauan sistematis: Efektifitas Palliative Home Care untuk Pasien

palliative care, and Journal of palliative medicine have be undertaken followed by analysis of the text words contained in the title and abstract, and of the index terms used to describe article. Studies published in English and in years 2000-2013 was considered for inclusion in this review. The reference list for additional studies following two textbooks: Oxford Textbook of Palliative Medicine (Hanks, 2009) and Oxford Textbook of Palliative Nursing (Ferrell, 2010). Initial keywords was utilize the MeSH term that commonly used: HIV/AIDS/terminal illness/ advance diseases AND palliative home care/ home-based palliative care OR inpatients palliative care/hospital-based palliative care AND used Patients outcomes/quality of life/ pain/symptoms/cost effective/satisfaction.

\section{Inclusion Criteria}

The quantitative component of this review will consider studies that evaluate delivering home palliative care which is providing comprehensive care and aiming at different physical and psychosocial components of palliative care, with the following outcome measures: quality of life, pain \& other symptoms, satisfaction of care, and cost effectiveness. Included patients with HIV/ AIDS and aged $\geq 18$ years old. The type of study included randomized controlled trials, non-randomized controlled trials, quasiexperimental, before and after studies, prospective and retrospective cohort studies.

\section{Data extraction}

Data were extracted by the reviewers and summarized by using the JBI data extraction tool. Collected data includes participant demographics, sample inclusion and exclusion criteria, study setting, number and reasons for withdrawal from study, type and description of complementary therapy intervention, application and follow up of intervention, measure of outcomes, statistical methods and study outcome descriptions.

\section{Assessment of methodological quality}

Methodological validity was processed by Appraisal instrument from the Joanna Briggs Institute (JBI). All papers selected for inclusion were subjected to a rigorous, independent appraisal to identify and select papers of the highest quality except those that minimize bias, and have good validity and precision. Expert opinion based on bench research or consensus.

\section{Results}

The literature searches generated 417 studies through searches of databases, excluding duplicates. From above number, we excluded the studies that were not included HIV/ADS

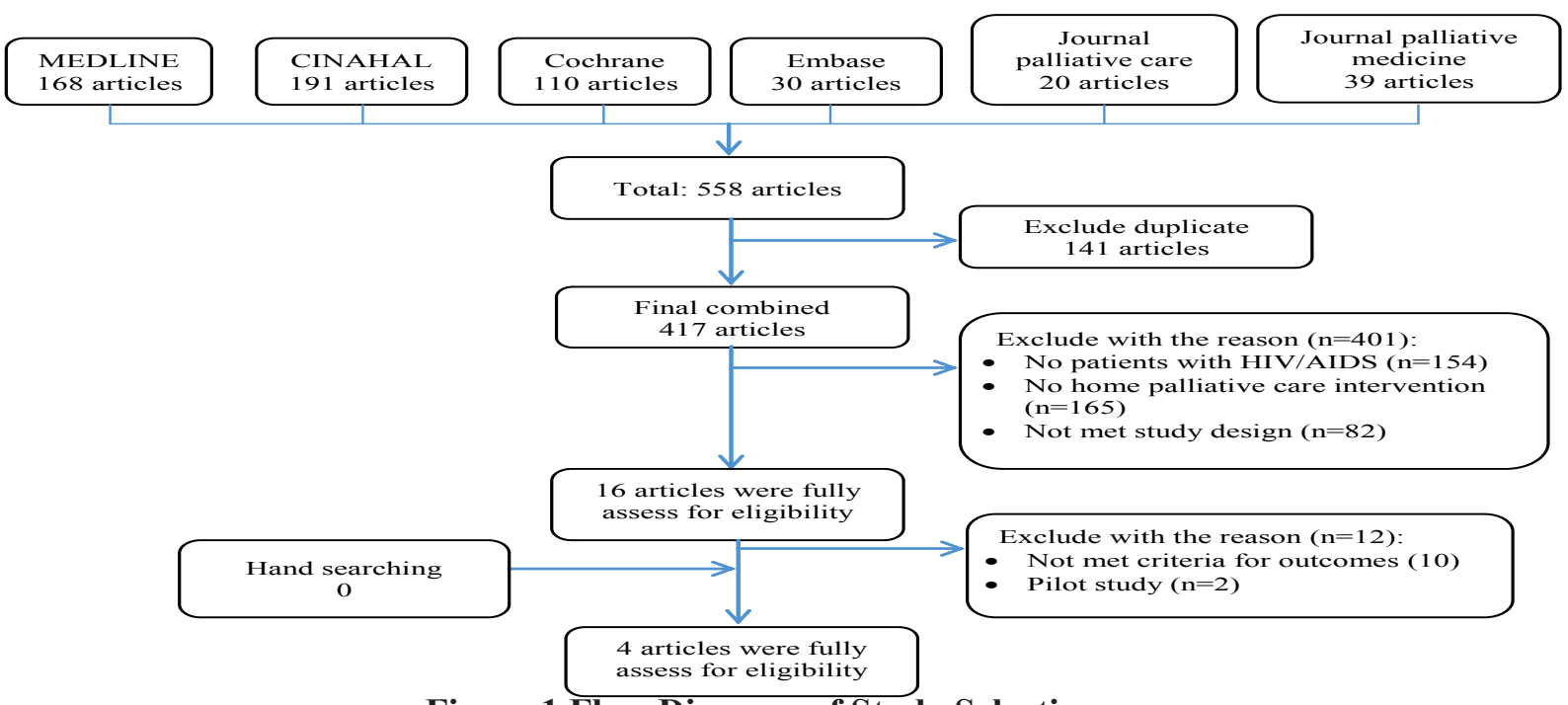

Figure 1 Flow Diagram of Study Selection 
Linlin Lindayani: Tinjauan sistematis: Efektifitas Palliative Home Care untuk Pasien

patients (401), not meet study design (82) and not use home palliative care as intervention (165). For total reviewed the full text of the remaining 16 articles. Of these, 2 studies were pilot study and will not be considered for review and 12 studies were not measured the major outcome for review. Finally, we decided 4 studies which have key strengths in design and measure important outcome to evaluate health care services to be reviewed. Moreover, these four studies applied models strengthening study design.

\section{Summary of Study Results}

Research on the effectiveness of home palliative care have reported the evidence of the benefit of home palliative care in helping patients die at home, improving patients outcome such as reducing symptoms, improve quality of life, increase satisfaction of care, and cost effectiveness. Review about effectiveness of palliative home care of one randomized control study and three prospective control studies that provided palliative home care services for patients with HIV/AIDS. The result of this review showed that palliative home care also effective in symptoms control such as anxiety, appetite, dyspnea, wellbeing, depression and nausea. Then, palliative home care also has been identified as an effective model in maintain overall quality of life. Besides that, patients, caregivers and physicians reported high satisfaction of palliative home care program scores around 93\%-96\%. Furthermore, palliative home care also showed cost effectiveness rather that hospital-based palliative care, can reduce the cost treatment per day $\$ 17.99$ as compared usual care (\$21.30). The difference between the costs per patient per day is statistically significant in reduced the cost for care. Moreover, patients also showed $100 \%$ compliance with advance care planning. One study also reported that people more likely to die at home $(47 \%)$ and showed that patients in hospice care had a longer average length of stay of 77.9 days.

\section{Results of assessment methodological quality}

The studies conducted in Randomized Control Trial (RCT) (Cherin et al, 2008) has been identified as a good quality of study with grade A of recommendation refers to JBI grading system. Random number charts has been used for allocation generation, allocation concealment using numbers on the charts were designated as either experimental or control group. Although blinding and loss to follow-up unclearly reported but it is not produce risk of bias because the major measurement is cost effectiveness that assess

\begin{tabular}{|c|c|c|c|c|c|}
\hline Authors & level & Participant & Method & Intervention & Outcome \\
\hline $\begin{array}{l}\text { Cherin et } \\
\text { al., } 2008\end{array}$ & $1 \mathrm{C}$ & $\begin{array}{l}549 \text { patients } \\
\text { with HIV/ } \\
\text { AIDS } \\
\text { who were } \\
\text { referred to } \\
\text { home care } \\
\text { services }\end{array}$ & $\begin{array}{l}\text { Randomized } \\
\text { Control Trial } \\
\text { - } \quad \text { Allocation } \\
\text { generation: } \\
\text { Random number } \\
\text { charts were used } \\
\text { Allocation } \\
\text { concealment: } \\
\text { numbers on } \\
\text { the charts were } \\
\text { designated } \\
\text { as either } \\
\text { experimental or } \\
\text { control group } \\
\text { Blinding: } \\
\text { unclear } \\
\text { Loss to follow- } \\
\text { up: not reported }\end{array}$ & $\begin{array}{l}\text { - Intervention Group: } \\
\quad \text { Trans-professional Model } \\
\text { - Control group: } \\
\quad \text { Standard Model of Home } \\
\text { Care } \\
\text { Intervention Group } \\
\text { In the Trans-professional Model, } \\
\text { all providers coordinate care and } \\
\text { combine bio-psychosocial services } \\
\text { into an integrated system of } \\
\text { blended care. } \\
\text { Control group } \\
\text { In the Standard Model of Home } \\
\text { Care Services, providers often } \\
\text { work independently and are } \\
\text { loosely coordinated by a Nurse } \\
\text { Case Manager. Oftentimes } \\
\text { services are duplicated and not } \\
\text { everyone focuses on the bio- } \\
\text { psychosocial services }\end{array}$ & $\begin{array}{l}\text { Per-day treatment costs } \\
: \$ 17.99 \text { vs } \$ 21.30(\mathrm{t}= \\
=2.44, \mathrm{p}<.01) \\
\text { The differential } \\
\text { between the two } \\
\text { models when reduced } \\
\text { to a ratio indicates } \\
\text { that for every dollar } \\
\text { of cost expended on } \\
\text { Trans-professional } \\
\text { group patients, the } \\
\text { cost expended for } \\
\text { Traditional group } \\
\text { patients was } 58 \text { cents } \\
\text { greater }(\$ 1.00 \mathrm{vs.} \\
\$ 1.08)\end{array}$ \\
\hline
\end{tabular}


Linlin Lindayani: Tinjauan sistematis: Efektifitas Palliative Home Care untuk Pasien

\begin{tabular}{|c|c|c|c|c|c|}
\hline Authors & level & Participant & Method & Intervention & Outcome \\
\hline $\begin{array}{l}\text { Goodwin et al., } \\
2003\end{array}$ & $2 \mathrm{C}$ & $\begin{array}{l}\text { Included patients with } \\
\text { HIV/AIDS } \\
\text { - } \quad \text { Intervention } \\
\text { - } \quad \text { Control } n=120\end{array}$ & $\begin{array}{l}\text { Prospectively } \\
\text { controlled study } \\
\text { - Follow up at } \\
\text { baseline, 6-8 } \\
\text { weeks, \& 12-15 } \\
\text { weeks } \\
\text { Five palliative day } \\
\text { care centers in the } \\
\text { UK }\end{array}$ & $\begin{array}{l}\text { Intervention Group: } \\
\text { Palliative day care: } \\
\text { as day care in a } \\
\text { hospice setting } \\
\text { Control Group: } \\
\text { Home palliative care }\end{array}$ & 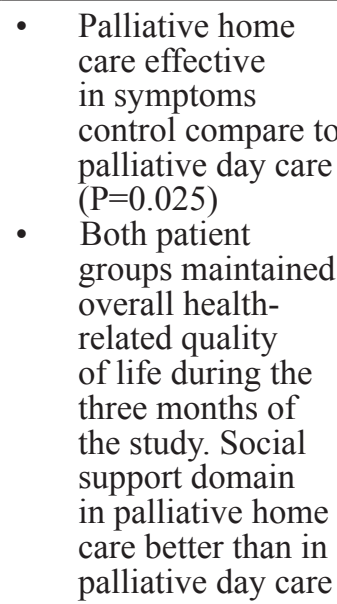 \\
\hline
\end{tabular}

\begin{tabular}{llll}
\hline Bookbinder et al., & 2C & Included patients with & $\begin{array}{l}\text { Prospective controlled } \\
\text { Bookbinder, }\end{array}$ \\
& HIV/AIDS n=499 et.al, & & study \\
& & & follow-up visits \\
& & & 20 times were \\
& & being conducted \\
& & per week
\end{tabular}

\begin{tabular}{ll}
\hline Kerr et al., 2014 $2 \mathrm{C}$ & Included patients with \\
& HIV/AIDS \\
& 499 Home \\
& Connections \\
& participants enrolled \\
& between July 1, 2008 \\
& and May 31, 2013 \\
&
\end{tabular}

\section{First Model}

The new palliative

home care team

included an NP and

an SW (PCHT-NPSW)

Second model

a hospice program

(Hospice-NP)
- $\quad$ Significant decline in symptom distress during the initial two weeks after referral $(\mathrm{P}=$ 0.003 )

- $\quad 100 \%$ compliance with advance care planning

$\begin{array}{ll}\text { A prospective } & \text { on call palliative care } \\ \text { study Secondary } & \text { nurse support. } \\ \text { data : database } & \\ \text { study of home } & \\ \text { care program } & \end{array}$

- The site of death was home for $47 \%$ of those who died during or after participation in the program.

- $\quad$ Six of eight symptom domains (anxiety, appetite, dyspnea, wellbeing, depression and nausea) showed improvement.

- $\quad$ Patients, caregivers and physicians gave high program satisfaction scores (93\%-96\%).

- Home connections participants who subsequently enrolled in hospice care had a longer average length of stay of 77.9 days as compared to all other hospice referrals (average length of stay 56.5 days). 
using computerized system. Two studies conducted retrospective controlled studies (Bookbinder et al., 2011) and (Goodwin et al., 2003) have a good quality of study because follow up measurement completely. This study have grade A recommendation also refer to JBI grading system. There were many participant loss of follow up from two studies but the result of this study showed statistically significant. One study by Kerr et al. (2014) used retrospective controlled study has high quality of study because follow up was completely measure over a sufficient time period without loss of participant in follow up process so this study also have large sample size. This study have grade A recommendation also refer to JBI grading system. Loss to follow-up and attrition bias are among the most problematic aspects to deal with because although most of the times the cause is 'natural' in palliative care (i.e. death), a high level of attrition jeopardizes the study's ability to produce enough data to conduct a powered analysis (which increases the chances of not detecting a significant difference when there is one).

\section{Discussion}

The result of this review showed that palliative home care for patients with HIV/ AIDS is effective in controlling symptoms. The results of this study was similar with study conducted in cancer population that emphasize palliative home care as an effective approach for reducing symptoms burden (Gomes et al., 2013). Another systematic review conducted in patients with HIV/AIDS but did not specified to palliative home care also found that with the systematic review analysis found that palliative care as an effective approach in improving pain and symptom control, reducing anxiety, increasing insight and the spiritual well-being (Harding et al., 2005). In addition, large evidence also has been reported that palliative care is effective in pain and symptoms control (Selwyn et al., 2003; Goodwin et al., 2003). Undoubtedly, palliative care is effective in reducing the pain and controlling another symptoms, including psychosocial problems.

Only one studies reported cost- effectiveness analysis of home-palliative care which found that home-palliative care has lower of per-day treatment cost compared to usual care. Our finding seems to corroborate with another systematic review conducted in cancer patients that found palliative home care can reduced the cost of treatment (Gomes et al., 2013). As better outcome improve from patients that receiving palliative home care, there is also improvement of patients and family satisfaction. These two outcome is important measure to evaluate the quality of care. However, there are limited studies on counted the cost-effectiveness and/or costbenefit of the treatment also satisfaction of those who give and receive care. Further research is warranted to evaluate the costeffectiveness of home-palliative care compared to usual care in patients with HIV/ AIDS in order to provide strong evidence and making adequate influence for health policy maker when designing palliative home care.

Attain an optimal quality of life is important goal of palliative care as stated in the WHO definition (WHO, 2002). However, in HIV/ AIDS cases, especially in Indonesia, stigma is a big issues, fear of being discriminated resulted for patients with HIV/AIDS tend not to disclose their HIV status to others, not use condoms to prevent HIV transmission, and not seek and receive treatment for HIV, which would affect their quality of life (Ford et al., 2004). Hence, home based care can be one of consideration to design effective palliative care for patients with HIV/AIDS in Indonesia. Furthermore, policy makers also can design base on the needs of patients with HIV/AIDS and home palliative care services may need expansion locally on the basis of current needs. Moreover, considering the cultural variations need to be take in into preparation in designing palliative care for patients with HIV/AIDS.

We only included 4 studies that meet our eligible criteria, it seem that HIV palliative care is important but reach on that need to be increased. A limitation of the evidence that found in this review is the diversity of the characteristics of home palliative care interventions and the control interventions called 'usual care'. Some of this heterogeneity relates to differences between countries and contexts but also in the proposed models 
Linlin Lindayani: Tinjauan sistematis: Efektifitas Palliative Home Care untuk Pasien

of home palliative care such as in the US 'hospice care' provide overall care including home nursing whereas UK models of home palliative care are more optional and not included in hospice care.

\section{Conclusions}

Palliative home care is effective in improving patients' symptoms, attain better quality of life, improve satisfaction and reduce health cost. The results provide reliable evidence that home palliative care for patients with HIV/AIDS is effective in improving patient's outcome compare to hospital-based palliative care. Thus, police maker can utilize the data to decide the effective model of palliative care for patients with HIV/AIDS since Indonesia is huge and archipelagic with sea-lane position fostered inter-island. However, more work is needed to analyze cost-effectiveness and appropriate outcomes of the palliative home care in patients with HIV/AIDS. Further primary research should be powered on how home-based care fits into the current treatment context in middle-income and lowincome countries because it does not yet exist. Further research must define better the usual care provided locally and what parts of the intervention are likely to produce benefits and what parts are less effective.

\section{References}

Bookbinder, M., McHugh, M., Higgins, Budis, J., \& Portenoy, R.K. (2011). Nurse practitioner-based models of specialist palliative care at home: Sustainability and evaluation of feasibility. Journal of Pain and Symptom Management, 41(1). doi:10.1016/j. jpainsymman.2010.04.011.

Cherin, D.A., Huba, G.J, Brief, D.E., \& Melchoir, L.A. (2008). Evaluation of the transprofessional model of home health care for HIV/AIDS. Home Health Care Services Quarterly, 17(1), 55-72. DOI: 10.1300/ J027v17n01 04.

Ferrell, B. R., Coyle, N., \& Paice, J. (Eds.). (2014). Oxford textbook of palliative nursing.
Oxford University Press. Oxford University Press.

Floyd \& Gilks, C. (2001). Cost and financing aspects of providinganti-retroviral therapy: A background paper. Retrieved from http:// www.worldbank.org/aids-econ/arv/floyd/ whoarv.pdf.

Ford, Kathleen, Wirawan, Dewa Nyoman, Sumantera, Gusti Made, Sawitri, Anak Agung Sagung, \& Stahre, Mandy. (2004). Voluntary HIV testing, disclosure, and stigma among injection drug users in Bali, Indonesia. AIDS Education and Prevention, 16(6), 487-498.

Gomes, B., Calanzani, N., Curiale, V., McCrone, P., \& Higginson, I.J. (2013). Effectiveness and cost-effectiveness of home palliative careservices for adults with advanced illness and their caregivers (Review). The Cochrane Library, 6. Art. No.: CD007760. DOI: 10.1002/14651858. CD007760.pub2.

Goodwin, D.M., Higginson, I.J., Myers, K., Douglas, H.-R., \& Normand, C.E. (2003). Effectiveness of palliative day care in improving pain, symptom control, and quality of life. Journal of Pain Symptom Management, 25(3), 202-212.

Hanks, G. W., Cherny, N. I., Christakis, N. A., \& Kaasa, S. (2011). Oxford textbook of palliative medicine. Oxford University Press.

Harding, R., \& Higginson, I.J. (2005). Palliative care in sub-Saharan Africa. Lancet, 365(9475), 1971-1977. doi: 10.1016/S01406736(05)66666-4.

Indonesia, M. o. h. o. R. I. (2013). Indonesia Health profile in 2013. www.depkes.go.id.

Jameson, C. (2007). The role of a palliative care inpatient unit in disease management of cancer and HIV patients. South African Medical Journal, 97(9), 849-852.

Kerr, C.W., Tangeman, J.C., Rudra, S.B., Grant, P.C., Luczkiewicz, D. ..., Serehali, A.M. (2014). Clinical impact of a homebased palliative care program: A hospice- 
Linlin Lindayani: Tinjauan sistematis: Efektifitas Palliative Home Care untuk Pasien

private payer partnership. Journal of Pain Symptom Management. doi.org/10.1016/j. jpainsymman.2014.02.003.

Kikule, E. (2003). A good death in Uganda: Survey of needs for palliative care for terminally ill people in urban areas. $B M J$, 327(7408), 192-194. doi: 10.1136/ bmj.327.7408.192.

Krakauer, E.L., Ngoc, N.T., Green, K., Van Kham, L., \& Khue, L.N. (2007). Vietnam: Integrating palliative care into HIV/ AIDS and cancer care. J Pain Symptom Manage, 33(5), 578-583. doi: 10.1016/j. jpainsymman.2007.02.004.

Selwyn, P.A., Rivard, M., Kappell, D., Goeren, B., LaFosse, H., Schwartz, C., ..., Post, L.F. (2003). Palliative care for AIDS at a large urban teaching hospital: Program description and preliminary outcomes. Journal of Palliative Medicine, 6(3), 461474.
Simms, V.M., Higginson, I.J., \& Harding, R. (2011). What palliative care-related problems do patients experience at HIV diagnosis? A systematic review of the evidence. Journal of Pain and Symptom Management, 42(5), 734-753. doi: 10.1016/j. jpainsymman.2011.02.014

WHO. (2002). WHO definition of palliative care. Retrieved from http://www.who.int/ cancer/palliative/definition/en/.

WHO. (2005). A community health approach to palliative care for HIV/AIDS and cancer patients.

Young, T., \& Busgeeth, K. (2010). Homebased care for reducing morbidity and mortality in people infected with HIV/AIDS (Review). The Cochrane Library, (1). Art. No.: CD005417. DOI: 10.1002/14651858. CD005417. 